\title{
SME Steeplechase: When Obtaining Money Is Harder Than Innovating
}

\author{
M. Belén Guercio ${ }^{1,2} \mathbb{D}$, Lisana B. Martinez ${ }^{1,2} \mathbb{D}$ and Aurelio F. Bariviera ${ }^{3, * \mathbb{C}}$ \\ 1 Instituto de Investigaciones Económicas y Sociales del Sur (IIESS), CONICET-UNS, \\ B8000CTX Bahía Blanca, Argentina; mbguercio@iiess-conicet.gob.ar (M.B.G.); \\ lbmartinez@iiess-conicet.gob.ar (L.B.M.) \\ 2 Universidad Provincial del Sudoeste, B8003FTH Bahía Blanca, Argentina \\ 3 Department of Business, Universitat Rovira i Virgili, 43206 Reus, Spain \\ * Correspondence: aurelio.fernandez@urv.cat; Tel.: +34-977759833
}

Received: 13 September 2018; Accepted: 13 May 2019; Published: 21 May 2019

\begin{abstract}
In this paper, we analyze the main characteristics of European Small and Medium Enterprises (SMEs), related to the demand for and access to external financial resources. We use microdata from an extensive database, elaborated by the European Central Bank and the European Commission: the Survey on the Access to Finance of Enterprises. Firstly, we consider a set of variables as determinants to the decision to apply for different financial instruments. Secondly, we use the same set of variables to analyze the actual access to these instruments. For each regression, several SMEs profiles were created, in order to detect SMEs archetypes according to their decisions. The results are thought-provoking, and highlight that differences in firms characteristics (size, innovative activities, etc.), influence not only the access to, but also the demand for external finance.
\end{abstract}

Keywords: financial decisions; innovative firms; EU; SME

JEL Classification: G21; G28; O3; O52

\section{Introduction}

Small and Medium Enterprises (SMEs) are commonly known as the backbone of the real economy. They represent $99.8 \%$ of all European business, which generate around $58 \%$ of the gross value added of the corporate sector in Europe. Furthermore, they are responsible for almost $67 \%$ of private sector employment, which represents 86.8 million people (Kaya 2014).

This concern highlights the importance of SMEs growth and their needs for external financing and the problems they have to face to solve market barriers.

In this sense, SMEs financial structure and its determinant is a wide subject of study that has changed over time and according to the set of SMEs analyzed, many factors affect their financial decisions. As it is commonly known, SMEs financial access is restricted due to large information asymmetries, agency risk, scarce physical collaterals, and specific activities and firm's characteristics (Berger and Udell 1998; Briozzo et al. 2016). In light of the 2008 financial crisis, many European markets suffered credit constrained problems. Ferrando et al. (2017) mention that investor confidence dropped in the banking sectors of those countries more affected by the turmoil, given that their banks tended to assign large portfolios to the debt securities issued by domestic sovereigns. Consequently, bank funding increased. Mc Namara et al. (2017) suggest that countries lending infrastructure influences SMEs capital structure due to the fact that SMEs debt is higher in countries with more efficient insolvency environments in terms of debt rescue and in countries with less rigorous regulatory laws because of the lower capital regulatory requirements for banks. Nonetheless, Kaya (2014) supports that SMEs 
in the countries that are the hardest hit by the recession and unemployment problems are those less favorable to get loans given the high level of lending rates.

Wehinger (2014) analyses the European SMEs and the credit crunch since the 2008 financial crisis and highlights that since that event, banks' perception of growing macro and micro risks have played an increasing role in the contraction of business credit standards and have reduced availability of external financing, despite country particularities.

It is true that the relationship between innovativeness and the probability to get financed has been previously studied. This study investigates if the SMEs financial access depends on the specific instrument demanded or on a set of variables that condition SMEs' profile to decide to apply for some specific financial instruments. Moreover, we deepen this aspect by considering the current access to the financial line regarding the same set of variables recognized as key determinants of SMEs capital structure. However, to the best of our knowledge, there are no others papers that split the financial aid application willingness from the financial aid application success. Precisely, this is the main contribution of this paper.

We conducted the empirical study on two homogeneous groups of countries: euro and non-euro EU countries.

Our results are consistent and contribute to the literature in different ways: First, there are no similar works that analyze this issue considering such a huge set of European countries, distinguishing the dependent variable between applying and accessing, and the different financial instruments. Second, the innovation variable is considered given the importance of its characteristic to SMEs decisions in line to their needs for external financial access. Third, SMEs profiles have been created in order to detect which kind of SMEs is more fortunate to access to specific financial instruments.

This paper is organized as follows: Section 2 presents the literature review of the main SMEs capital structure theories and a revision of SMEs' empirical works related to their capital structure decisions. Section 3 describes the data and Section 4 the methodology applied for the study. Section 5 presents the results of the study and discusses the main findings. Finally, Section 6 provides an analysis regarding the main conclusions of the work.

\section{Literature Review}

\subsection{SMEs Financial Structure}

Previous literature studies the sundry traditions usually considered by SMEs in financing their activities. Since 1950, capital structure has developed into a controversial research area in the field of corporate finance (Forte et al. 2013).

One of the traditional debates on this concern comes from Modigliani and Miller (1958), who considered that the market value of each enterprise is independent of its capital structure. Some years later, Modigliani and Miller (1963) studied the possibility to dismiss the original assumptions of perfect competition markets and admit that indebtedness has a tax advantage given that interests are deductible from the income tax. Even so, it does not mean that companies must at all times try to use debt. The authors highlight the existence of other relevant factors in the financing decisions that are not considered within the context of the equilibrium static models.

In this context, the Trade-off theory raises, and considers the effects of the entire industry (taxes, bankruptcy costs, and agency problems) and predicts an optimal structure as a result of balancing costs and the benefits of issuing debt and capital. In this framework, leverage is considered advantageous (under certain conditions) and managers choose to use debt even if there are internal funds available. This theory assumes that the optimal capital structure is the result of equalizing the benefits of leverage (mainly tax savings) and the costs of financial difficulties. It also proposes to avoid the extreme use of leverage and rationalize the indebtedness indexes (Brealey et al. 2006).

On the other side, Myers (1984) and Myers and Majluf (1984) propose the Pecking Order Theory, which describes a hierarchy in financing choices and has as its central axis the asymmetric information 
between lenders and borrowers. Due to the fact that companies have more information on their future than lenders, the need for control increases borrowing costs, which encourage companies to be financed with internal funds in the first place. In this line, companies prefer the reinvestment of profits, in order to avoid adverse selection problems. When these funds have been exhausted, companies are financed with bank debt, and lastly, in the stock market. The proponents of the Pecking Order Hypothesis explain that this hierarchical order is the result of greater flexibility and lower transaction costs of internal versus external resources. In this stream, the leverage is considered to be disadvantageous compared to the use of internal sources (Briozzo et al. 2016; Martinez et al. 2017).

The last financial crisis that burst in 2008 and its consequences and collateral effects spread to many European economies and sometime later affected strongly the interbank market. This crucial source of liquidity for banks in Europe brought changes in corporate lending, leading to a credit crunch in several Eurozone countries (Drehmann and Nikolaou 2013; Iyer et al. 2014). Many works analyze the effects and consequences of the last financial crisis on SMEs development, considering that the financial system has been altered, and consequently the financial access of such firms changed (Armstrong et al. 2013; Cowling et al. 2012; Lee et al. 2015).

Many works have studied the SMEs capital structure during different periods of time, and find that, according to different samples of firms, some of them finance their activities in accordance with the pecking order (Yazdanfar and Öhman 2015;Balios et al. 2016). Others highlight the importance of the trade-off theory to explain the financial behavior of SMEs (Rossi et al. 2015; Banga and Gupta 2017) and some others argue that theories are complementary (Serrasqueiro and Nunes 2012; Serrasqueiro and Caetano 2015; Mc Namara et al. 2017).

\subsection{Innovative SMEs}

The differences between innovative SMEs and traditional SMEs, which intensify the problems of access to external financing of the former, have promoted several studies that test the results of capital structure theories in innovative SMEs. These empirical works have found coincidences and dissidence when evaluating whether the traditional theories explain the capital structure of innovative SMEs. Cassia and Minola (2012) find that companies follow the financial hierarchy theory in the first years of life, but then prioritize capital increase instead of bank indebtedness. The same results are found by Minola et al. (2013) and Hogan and Hutson (2005). These last authors highlight that this financial structure not only comes from financial constraints (on the supply side), but is a consequence of the preferences of the SMEs owners of innovators that, unlike traditional SMEs, they do not have a deep-rooted desire for independence, and, as a consequence, they prefer to share the company's ownership instead of borrowing in the financial system.

Hogan et al. (2017) find that venture capitalists and angel investors are in second place, after domestic financing. Guercio et al. (2016), considering a group of innovative Argentine SMEs, find that first SMEs use internal resources and then finance their activities with current liabilities, mainly suppliers, and finally, loans from financial institutions. Ullah and Taylor (2007) find that funds from personal savings are listed as the main source of financing, followed by capital risk, and mortgage loans. On the other hand, Giudici and Paleari (2000) and Guercio et al. (2017) find that innovative firms use short term debt and commercial credit lines only in case that internal resources are not their sufficient to fund the investment projects. Pierrakis and Saridakis (2019) study the interaction between venture capitalists and other players of the innovation ecosystem, in order to overcome information asymmetries. In the course of the business life, firms can get access to other types of financing such as debt or capital increase. The financial constraints faced by innovative SMEs especially sensitive. Innovation is intrinsically a risky activity since it is concerned with the introduction of a new product, method, or device with an uncertain outcome. This situation turns financial decision riskier Coad and Rao (2008). Moreover, asymmetric information can preclude innovative unexperienced firms from external financial resources (Sullivan 2014). In fact, credit scoring for micro-entrepeneurs relies heavily on information that is not easily available to the financial 
institution, in case of newly established firms/individuals, as reported in Lanzarini et al. $(2015,2017)$ and Jimbo Santana et al. $(2017,2018)$. It is also critical the lack of hard collateral in most innovative firms, whose main assets could be intangible, and sometimes unuseful outside the firm itself (Mina et al. 2013). Moritz et al. (2016) comment that innovative SMEs are more financially constrained given the huge risk of innovation, the informational opaqueness of the projects for external capital providers, and the low diversification of SMEs possibilities (Ang 1992). Takalo and Tanayama (2010) find that public Research and Development subsidies help to reduce the financing constraints of technology-based entrepreneurial firms in a double way: (i) reducing the financial amount requested to the banks, and (ii) signaling firms with promising projects.

\section{Data}

To pursue our research objective, we use microdata from the European Commission and European Central Bank, collected in the Survey on Access to Finance of SMEs (SAFE survey). This survey contains information of reliable financial sources of SMEs financing, since 2009.

The survey is conducted biannually on a given set of questions. Each round is of a different type of survey. The more comprehensive one is done on all EU countries plus some neighboring countries. The limited survey is run on a limited number of euro area countries. Considering that the aim of this paper is to study SME financial constraints across time, we used the more comprehensive survey, in order to consider more countries. The years under analysis are 2009, 2011, 2013, 2014, and 2015.

Moreover, the questionnaire includes the key question regarding the innovation done during the last twelve months for the firms, considering if they have introduced a new or significantly improved product or service to the market, or process or method, a new organization of management or a new way of sales. The whole sample includes data of around 40,000 companies in 28 European countries. See Table 1 in order to get detailed information on countries included.

Table 1. Countries included in the sample.

\begin{tabular}{ccll}
\hline \multicolumn{2}{l}{ Euro Area Countries } & \multicolumn{2}{l}{ Other EU Member States } \\
\hline AT & Austria & BG & Bulgaria \\
BE & Belgium & HR & Croatia \\
CY & Cyprus & CZ & Czech Republic \\
EE & Estonia & DK & Denmark \\
FI & Finland & HU & Hungary \\
FR & France & PL & Poland \\
DE & Germany & RO & Romania \\
GR & Greece & SE & Sweden \\
IE & Ireland & UK & United Kingdom \\
IT & Italy & & \\
LT & Lithuania & & \\
LV & Latvia & & \\
LU & Luxembourg & & \\
MT & Malta & & \\
NL & Netherlands & & \\
PT & Portugal & & \\
SK & Slovakia & & \\
SI & Slovenia & & \\
ES & Spain & & \\
\hline
\end{tabular}

Moreover, the survey encloses information related to SMEs characteristics such as size (the number of employers and turnover), sector, firm age, ownership, the fact that the firm is involved or not in product and/or process enhancement/innovation, and their recent financial sources requests. In addition, it contains information on the different financial instruments used by firms. Several works used this database previously (Öztürk and Mrkaic 2014; Ferrando and Mulier 2015; Lawless et al. 2015; 
Moritz et al. 2016). For a detailed methodological information on this survey see European Central Bank (2017).

The variables selected and their descriptions are represented in Tables 2 and 3. The variables considered in this work are those which, according to previous literature, influence SMEs financial access or affect their capital structure.

Tables 4 and 5 show the percentage of firms that applied and accessed to a given financial instrument, at global and country level.

Table 2. Selected dependent variables description.

\begin{tabular}{|c|c|}
\hline $\begin{array}{l}\text { Dependent } \\
\text { Variables }\end{array}$ & Description \\
\hline Apply_cl & $\begin{array}{l}\text { Binary variable that takes } 1 \text { if the firm applied for credit line, bank overdraft, or credit } \\
\text { card overdraft in the past } 6 \text { months and } 0 \text { if it did not apply. This dependent variable } \\
\text { shows the demand of credit line. }\end{array}$ \\
\hline Apply_bl & $\begin{array}{l}\text { Binary variable that takes } 1 \text { if the firm applied for bank loans in the past } 6 \text { months and } \\
0 \text { if it did not apply. This dependent variable shows the demand of bank loans. }\end{array}$ \\
\hline Apply_tc & $\begin{array}{l}\text { Binary dichotomous variable that takes } 1 \text { if the firm applied for trade credit in the } \\
\text { past } 6 \text { months and } 0 \text { if it did not apply. This dependent variable shows the demand of } \\
\text { trade credit. }\end{array}$ \\
\hline Apply_of & $\begin{array}{l}\text { Binary variable that takes } 1 \text { if the firm applied to other external financing in the past } \\
6 \text { months and } 0 \text { if it did not apply. This dependent variable shows the demand of } \\
\text { other external financing as loans from a related company, shareholders or family and } \\
\text { friends, leasing, factoring, grants, subordinated debt instruments, participating loans, } \\
\text { peer-to-peer lending, crowdfunding, and issuance of equity and debt securities }\end{array}$ \\
\hline Access_cl & $\begin{array}{l}\text { Success in obtaining short term bank financing. It is a dichotomous variable that takes } \\
1 \text { if the firm obtained all credit line, bank overdraft or credit card overdraft that has } \\
\text { applied in the past } 6 \text { months and } 0 \text { otherwise. This dependent variable shows the access } \\
\text { of short term bank financing }\end{array}$ \\
\hline Access_bl & $\begin{array}{l}\text { Success in obtaining loans. It is a dichotomous variable that takes } 1 \text { if the firm obtained } \\
100 \% \text { of the bank loan which has applied in the past six months, and } 0 \text { otherwise. } \\
\text { This dependent variable shows the access of long term bank financing }\end{array}$ \\
\hline Access_tc & $\begin{array}{l}\text { Success in obtaining trade credit. It is a dichotomous variable that takes } 1 \text { if the firm } \\
\text { obtained all trade credit requested in the past six months, and } 0 \text { otherwise. }\end{array}$ \\
\hline Access_of & $\begin{array}{l}\text { Success in obtaining other external financing. It is a dichotomous variable that takes } 1 \text { if } \\
\text { the firm obtained } 100 \% \text { of all other external financing requested in the past six months, } \\
\text { and } 0 \text { otherwise. }\end{array}$ \\
\hline
\end{tabular}


Table 3. Selected independent variables description.

\begin{tabular}{|c|c|}
\hline $\begin{array}{l}\text { Independent } \\
\text { Variables }\end{array}$ & Description \\
\hline Turnover_micro & $\begin{array}{l}\text { It is a dummy that takes } 1 \text { if the firm's turnover is up to } 2 \text { million euros; and } 0 \text { in } \\
\text { another case }\end{array}$ \\
\hline Turnover_small & $\begin{array}{l}\text { It is a dummy that takes } 1 \text { if the firm's turnover is between } 2 \text { million euros and up to } 10 \\
\text { million euros; and } 0 \text { in another case. }\end{array}$ \\
\hline Turnover_medium & $\begin{array}{l}\text { It is a dummy that takes } 1 \text { if the firm's turnover is between } 10 \text { million euros and up to } \\
50 \text { million euros; and } 0 \text { in another case. (Base) }\end{array}$ \\
\hline Industry & $\begin{array}{l}\text { It is a dummy that takes } 1 \text { if the firms belong to the industry sector; and } 0 \text { in another } \\
\text { case (Base). }\end{array}$ \\
\hline Services & It is a dummy that takes 1 if the firms belong to the service sector; and 0 in another case. \\
\hline Trade & It is a dummy that takes 1 if the firms belong to the trade sector; and 0 in another case. \\
\hline Construction & $\begin{array}{l}\text { It is a dummy that takes } 1 \text { if the firms belong to the construction sector; and } 0 \text { in } \\
\text { another case. }\end{array}$ \\
\hline Age5 & It is a dummy that takes 1 if the firm's age is up five years old and 0 in another case. \\
\hline Age5_10 & $\begin{array}{l}\text { It is a dummy that takes } 1 \text { if the firm's age is between five and } 10 \text { years old and } 0 \text { in } \\
\text { another case. }\end{array}$ \\
\hline Age10 & $\begin{array}{l}\text { It is a dummy that takes } 1 \text { if the firm's age is more than ten years old, and } 0 \text { in } \\
\text { another case. }\end{array}$ \\
\hline Innova & $\begin{array}{l}\text { Dummy variable that reflects that the enterprise has introduced a new or significantly } \\
\text { improved product or service to the market or a new or significantly improved } \\
\text { production process or method in the last } 12 \text { months. It takes } 1 \text { if the answer is positive } \\
\text { and } 0 \text { otherwise. }\end{array}$ \\
\hline Innova_micro & $\begin{array}{l}\text { Interaction binary variable between firm size and innova. It takes } 1 \text { if the firm is } \\
\text { innovative and micro, and } 0 \text { otherwise. }\end{array}$ \\
\hline Innova_young & $\begin{array}{l}\text { Interaction binary variable between firm age and innova. It takes } 1 \text { if the firm is } \\
\text { innovative and up to five years old, and } 0 \text { otherwise. }\end{array}$ \\
\hline Zone & $\begin{array}{l}\text { Dummy variable that classify countries. It takes } 1 \text { if the firm is in the euro area, and } 0 \text { if } \\
\text { it is in a non-euro EU country. }\end{array}$ \\
\hline ownership & Dummy variable that takes 1 if the firm's ownership is a family, and 0 otherwise. \\
\hline Reatined & $\begin{array}{l}\text { Dummy variable that takes } 1 \text { if retained earnings or sale of assets are relevant sources } \\
\text { of finance of the firm, and } 0 \text { otherwise. }\end{array}$ \\
\hline tc & $\begin{array}{l}\text { Dummy variable that takes } 1 \text { if trade credit is a relevant source of finance of the firm, } \\
\text { and } 0 \text { otherwise. }\end{array}$ \\
\hline$b l$ & Dummy variable that takes 1 if bank loan is a relevant source of finance of the firm. \\
\hline$c l$ & $\begin{array}{l}\text { Dummy variable that takes } 1 \text { if credit line is a relevant source of finance of the firm, } \\
\text { and } 0 \text { otherwise. }\end{array}$ \\
\hline
\end{tabular}

Table 4. Descriptive statistics of selected dependent variables, for the whole database.

\begin{tabular}{lrrcccccc}
\hline Zone & apply_cl & apply_bl & apply_tc & apply_of & access_cl & access_bl & access_tc & access_of \\
\hline Euro area & $26 \%$ & $28 \%$ & $20 \%$ & $14 \%$ & $58 \%$ & $62 \%$ & $60 \%$ & $69 \%$ \\
Non-euro area & $24 \%$ & $19 \%$ & $19 \%$ & $14 \%$ & $70 \%$ & $64 \%$ & $69 \%$ & $70 \%$ \\
Total & $25 \%$ & $25 \%$ & $19 \%$ & $14 \%$ & $62 \%$ & $63 \%$ & $63 \%$ & $70 \%$ \\
\hline
\end{tabular}


Table 5. Descriptive statistics of selected dependent variables by country. Shaded cells highlight the greatest and lowest value of each dependent variable.

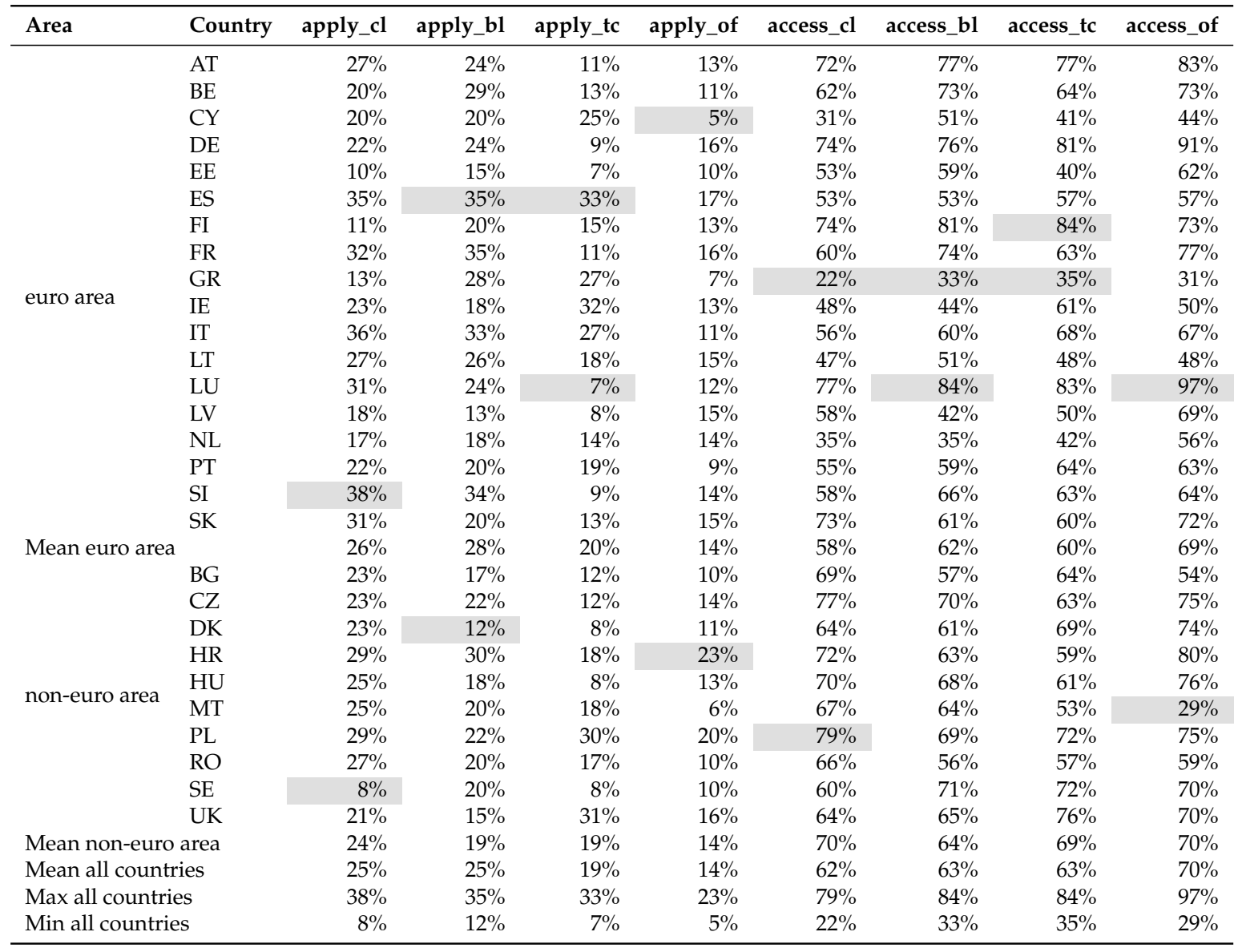

\section{Methodology}

In this work, we use regression models for binary outcomes, given that the dependent variables are binary. We estimate two models, one of them to analyze the decision to apply for different financial instruments and the other one to analyze the access to these financial instruments. The objective of this paper is to detect if the independent variables effect over the applied probability to some financial instruments and over the access probability are similar in both models.

Binary logit models are used to estimate the outcome of the dichotomous variable, given a latent variable. The latent variable $y^{*}$ is a linear function of the explanatory variables, using Equation (1):

$$
y^{*}=x_{i} \beta+\mu
$$

The higher the value of $y^{*}$, the greater the probability of occurrence of the event. In our case, the events are the probability of applying for a bank loan and the probability to get the application approved. The observed variable is related to the latent variable $y^{*}$ in the following way:

$$
y_{i}= \begin{cases}1 & \text { if } y_{i}^{*}>0 \\ 0 & \text { if } y_{i}^{*} \leq 0\end{cases}
$$

So, the event probability is defined as:

$$
\begin{aligned}
\operatorname{Pr}\left(y_{i}=1 \mid x\right) & =\operatorname{Pr}(x, \beta+\mu) \\
& =F(x \beta)
\end{aligned}
$$


Where $F$ is the cumulative distribution function for the logistic distribution with variance $\pi^{2} / 3$. The binary regression model is nonlinear. The independent variable effect over the dependent variable depends on its own value and on the whole variables included in the model. Therefore, it is not possible to obtain only one coefficient for each independent variable. Consequently, the interpretation of relationship between independent and dependent variable is not valid. Then, in this work, we interpreted the results with predicted probabilities. Given that, all independent variables are categorical. Furthermore, we use the profile estimation probabilities. Different profiles are created considering the main interesting firms' features for this research. In this sense, different values for the independent variables are fixed. Consequently, the change in the predicted probabilities related to each profile can be observed.

\section{Empirical Analysis and Results}

Table 6 presents the descriptive statistics of the interaction of variables reflecting financial application or access and innovation. It can be observed that innovative firms (independently of size, age, or other characteristics) apply more for financial aid than non-innovative firms. These proportions are statistically different at $1 \%$ significance level. However, it can be observed that innovative firms are less successful regarding effective financial access than non-innovative firms. These proportions are statistically different at the $1 \%$ and $5 \%$ signficance levels, depending on the financial instrument.

Table 6. Descriptive statistics of selected financial application and financial access dependent variables, interacting with innovation characteristics of the firms.

\begin{tabular}{|c|c|c|c|c|c|c|c|c|c|c|}
\hline \multicolumn{5}{|c|}{ Application } & \multicolumn{6}{|c|}{ Access } \\
\hline Financial Instrument & \multicolumn{2}{|c|}{ Innovation } & & & \multicolumn{2}{|c|}{ Financial Instrument } & \multicolumn{2}{|c|}{ Innovation } & & \\
\hline apply_cl & Innova $=0$ & Innova $=1$ & Total & $\mathrm{N}$ & & access_cl & Innova $=0$ & Innova $=1$ & Total & $\mathrm{N}$ \\
\hline 0 & 77.44 & 71.25 & 74.67 & 22716 & & 0 & 36.10 & 39.47 & 37.81 & 2816 \\
\hline Total & 100.00 & 100.00 & 100.00 & 30390 & & Total & 100.00 & 100.00 & 100.00 & 7411 \\
\hline & \multicolumn{4}{|c|}{ Pearson chi $2=123.8560 ; p$-value $=0.000$} & & & \multicolumn{4}{|c|}{ Pearson chi $2=4.1734 ; p$-value $=0.041$} \\
\hline 1 & 21.74 & 27.42 & 24.26 & 9625 & & 1 & 65.36 & 60.47 & 62.91 & 5962 \\
\hline \multirow[t]{2}{*}{ Total } & 100.00 & 100.00 & 100.00 & 39675 & & Total & 100.00 & 100.00 & 100.00 & 9463 \\
\hline & \multicolumn{4}{|c|}{ Pearson chi $2=140.2956 ; p$-value $=0.000$} & & & \multicolumn{4}{|c|}{ Pearson chi2 $=11.8621 ; p$-value $=0.001$} \\
\hline apply_tc & & & & & & access_tc & & & & \\
\hline 0 & 82.24 & 77.19 & 80.02 & 24710 & & 0 & 34.93 & 37.38 & 36.16 & 2172 \\
\hline 1 & 17.76 & 22.81 & 19.98 & 6178 & & 1 & 65.07 & 62.62 & 63.84 & 3862 \\
\hline 1 & 11.85 & 16.70 & 14.01 & 4846 & & 1 & 71.96 & 68.98 & 70.37 & 3351 \\
\hline \multirow[t]{2}{*}{ Total } & 100.00 & 100.00 & 100.00 & 34613 & Total & & 100.00 & 100.00 & 100.00 & 4787 \\
\hline & \multicolumn{6}{|c|}{ Pearson chi $2=133.2070 ; p$-value $=0.000$} & \multicolumn{4}{|c|}{ Pearson chi $2=4.1546 ; \mathrm{p}$-value $=0.042$} \\
\hline
\end{tabular}

Table 7 presents the obtained results of the logit model for the different financial instruments: credit line, bank loan, trade credit, and other financial instruments, and the independent variables detailed in Table 3.

Our results detect that micro firms have a negative significant coefficient, meaning that being a micro firm affect negatively the probability to apply for the different financial instruments. With respect to small firms, this characteristic affects the effective financial access more than the application for external financial aid.

The firms' age variable is significant for those firms that have more than five years. Older firms ( 5 or more years old) ask less for trade credit lines or other financial resources. However, they are better at effectively securing any kind of external financial resources. In other words, for firms that present a wide seniority in the markets, the probability to demand a trade credit and other external financial instrument decreases, but their effective financial access increases. 
The fact that firms have innovated in a process, product, or service affects positively the probability to demand financial sources. The same result is obtained if the firms use internal sources.

Respect to the sector that the firms belong to, and considering the industrial sector as categorical base, the probability to demand bank financing, regarding short term instruments (credit lines) and medium and large terms (bank loan) sources and finance through trade credit diminish if the firms belong to the service sector.

The firms that belong to the trade sector affect negatively the probability to demand a bank loan and other external financial instruments. The construction sector affects positively the probability to demand credit lines and trade credit.

According to these results, if the firms are family businesses, they have higher probabilities to apply to trade credit. Respect to the other financial instruments, this variable is not significant.

Table 7 also presents the results of the probability estimation of SMEs that have accessed to the financial source demanded previously. In the same line as the probability estimation of demand, the firms' size is significant for all the instruments considered. Therefore, micro and small firms diminish the probabilities to have access to external finance, such as the theory of the capital structure predicts.

Moreover, if we consider the productive sector of the firms, belonging to the trade and construction sectors diminishes the probability in accessing a bank loan or a trade credit with respect to the industrial sector. Also, belonging to the construction sector affects negatively to the access to credit lines.

The firms age is positively correlated with the probability of access. Firms that are betwee 5 years old or more present higher probabilities in accessing credit lines, bank loans, or trade credit than those that are less than 5 years old (base category). Moreover, the probability related to the access to other financial resources is higher for firms that are 10 or more years old than those that are younger.

The probability of accessing a credit line, a bank loan, or trade credit diminishes if the firms innovate. However, innovative firms are better at accessing other financial resources. In general, we observe that innovative firms have higher probabilities to demand financial instruments but fewer probabilities in accessing them. These results could indicate that innovative firms present higher needs of external financial aid, but their access is limited.

Table 7. Logit model with dependent variables Apply and Access to the different financial instruments.

\begin{tabular}{|c|c|c|c|c|c|c|c|c|}
\hline Variable & apply_cl & apply_bl & apply_tc & apply_of & access_cl & access_bl & access_tc & access_of \\
\hline turnover_micro & $-0.0492 *$ & $-0.5090 * * *$ & $-0.3813^{* * *}$ & $-0.4243 * * *$ & $-0.4697^{* * *}$ & $-0.5635 * * *$ & $-0.1935^{* * *}$ & $-0.5669 * * *$ \\
\hline turnover_small & $0.111^{* * *}$ & $-0.1419^{* *}$ & 0.0000 & 0.0285 & $-0.1977^{* *}$ & $-0.1603^{* * *}$ & $-0.1477^{* * *}$ & -0.1341 \\
\hline services & $-0.1430 * * *$ & $-0.1241 * * *$ & $-0.4777^{* * *}$ & 0.0344 & -0.0671 & -0.0982 & -0.0470 & 0.1142 \\
\hline trade & -0.0477 & $-0.1172 * * *$ & 0.00000 & $-0.3830 * * *$ & -0.1039011 & $-0.0926^{* *}$ & $-0.1595^{* *}$ & 0.0015 \\
\hline construction & $0.1239 * * *$ & 0.0025 & $0.0825 * *$ & -0.0452 & $-0.1955 * *$ & $-0.1837 *$ & $-0.2995 * *$ & 0.0482 \\
\hline age5_10 & 0.0811 & 0.0016 & $-0.1594 *$ & $-0.1174 *$ & $0.3329 * * *$ & 0.3043 * & 0.1972 * & 0.0756 \\
\hline age10 & -0.0610 & -0.0164 & $-0.1781 * * *$ & $-0.2384 * *$ & $0.3088^{* * *}$ & $0.2811 * * *$ & $0.3165 * *$ & $0.2713 * *$ \\
\hline innova & $0.2853 * * *$ & $0.2653 * *$ & $0.2321 * *$ & $0.3151 * * *$ & $-0.1913^{* * *}$ & $-0.0468^{* *}$ & $-0.1532 * * *$ & 0.1416 ** \\
\hline ownfe & -0.011 & -0.043 & $0.3051 *$ & 0.0244 & 0.0479 & 0.0482 & $0.1286 *$ & 0.0964 \\
\hline zonaeuro & $0.1567^{* * *}$ & $-0.4945^{* * *}$ & 0.0000 & 0.0204 & $0.5576^{* * *}$ & $0.5589 * * *$ & $0.4353 * * *$ & 0.0725 \\
\hline retained & $0.9712 * * *$ & $0.2133 * * *$ & $0.2827 * * *$ & $0.2471^{* * *}$ & $\operatorname{sig}(+) * * *$ & 0.1001 & $0.1468^{* * *}$ & 0.0265 \\
\hline cl & . & $0.2133 * * *$ & $0.5057^{* * *}$ & $0.3871^{* * *}$ & & 0.3602 & $-0.1204^{* * *}$ & -0.0428 \\
\hline bl & $0.2741 * * *$ & . & $0.42502 * * *$ & $0.3951 * * *$ & $\operatorname{sig}(+) * * *$ & & $0.1291 * * *$ & $0.1959 * * *$ \\
\hline tc & $0.2741 * * *$ & $0.2927 * * *$ & . & $0.2614 * * *$ & $\operatorname{sig}(-) * * *$ & -0.2480 & . & $-0.2980 * * *$ \\
\hline \multicolumn{9}{|l|}{ Statistics } \\
\hline $\mathrm{N}$ & 30,697 & 39,675 & 30,888 & 34,613 & 7411 & 9463 & 6034 & 4787 \\
\hline 11_0 & $-17,392,319$ & $-22,032,052$ & $-15,531,546$ & $-14,068,061$ & $-49,198,196$ & $-6,239,248$ & $-39,465,984$ & $-29,207,251$ \\
\hline 11 & -16481 & -20846859 & -14728661 & -13506 & -47819828 & -6107242 & -38925855 & -28642493 \\
\hline chi2 & $17,935,252$ & $22,758,842$ & $15,305,323$ & $11,305,754$ & $26,135,698$ & $25,665,082$ & $10,355,111$ & $11,025,484$ \\
\hline r2_p & 0.0524 & 0.0538 & 0.0517 & 0.0400 & 0.0280 & 0.0212 & 0.0137 & 0.0193 \\
\hline aic & $32,990,199$ & $41,721,718$ & $29,485,322$ & $27,041,999$ & $95,919,657$ & $12,242,484$ & $7,813,171$ & $57,584,986$ \\
\hline bic & $33,106,846$ & $41,841,957$ & $29,602,055$ & $27,168,779$ & $96,887,158$ & $12,342,656$ & $79,070,433$ & $58,556,034$ \\
\hline
\end{tabular}

In order to analyze the goodness of fit, the likelihood of the model (with and without the intercept), the McFadden R2 and the probability of success (Count) are calculated. The results show that in all estimates the Log-likelihood Model is greater than the Log-likelihood Intercept-only. The $p$-value of 
LR ( dif $=10)$ indicates that the null hypothesis is rejected. The model is explained only by the constant. The McFadden and the McFadden (adjusted) indicate the goodness of fit of the model for the data is based on the comparison of the likelihood of the model only with the constant, with the likelihood of the model with all the estimated parameters. Finally, the Count compares the values observed in the sample with those predicted in the model. In all cases the Count Index is high (above 0.5), indicating that there are a high number of cases in which the prediction derived from the regression model achieves what is observed in the sample.

We created different firm profiles, according to size and engagement in innovation activities. These profiles present the same characteristics respect to the sector (all of them belong to the industrial area), use of internal sources to finance their activities, the firms are not family businesses, and they belong to the euro area.

The aim of the profile analysis is to evaluate the change in the probability to apply different instruments according to size and innovation. Consequently, we could determine the archetype firm which is more or less affected in financial application and access. The different firms' profiles are presented in Table 8 .

Table 8. Firms' profiles.

\begin{tabular}{cl}
\hline Profile & Characteristics \\
\hline $\mathbf{1}$ & Micro innovative firm \\
$\mathbf{2}$ & Small innovative firm \\
$\mathbf{3}$ & Medium innovative firm \\
$\mathbf{4}$ & Micro not innovative firm \\
$\mathbf{5}$ & Small not innovative firm \\
$\mathbf{6}$ & Medium not innovative firm \\
\hline
\end{tabular}

Considering the profiles created, the probabilities of firms' demands for each instrument have been created. The aim of this result is to show a compact vision of each profile result and the financial instruments. The probabilities obtained are presented in Table 9, in decreasing order for each financial instrument. For example, regarding financial application, Profile 2 has a probability of 0.5559 . This means that among all the firms within profile $2($ Small $=1$, Innova $=1)$, there is a probability equal to 0.5559 to apply for credit line. At the same time, firms within Profile 2, which actually applied for a credit line, have a probability of 0.5491 to really access to the credit line they have requested. The probability to access a given financial instrument was computed only with the firms that actually applied for such instrument. We can observe that in general innovative firms (Profiles 2 and 3) show greater probability to demand external financial aid. However, non-innovative firms reach the highest positions regarding the effective access to financial instruments (Profiles 5 and 6). If we look at firm size, micro firms (Profiles 1 and 4), irrespective of innovation activities, demand less and access less external finance. If we focus simultaneously on firm size and innovation, micro innovative firms (Profile 1) have one of the lowest application probabilities and the lowest financial access in all instruments. It is observed that medium firms (Profiles 3 and 6) present higher probability in accessing any instruments than micro firms (Profiles 1 and 4), as the financial theories predict. 
Table 9. Predicted probability of financial application and access.

\begin{tabular}{|c|c|c|c|c|c|c|c|}
\hline \multicolumn{8}{|c|}{ Financial Application } \\
\hline \multicolumn{2}{|c|}{ Credit line } & \multicolumn{2}{|c|}{ Bank loan } & \multicolumn{2}{|c|}{ Trade credit } & \multicolumn{2}{|c|}{ Other finance } \\
\hline Profile 2 & 0.5559 & Profile 3 & 0.5863 & Profile 3 & 0.4624 & Profile 2 & 0.3755 \\
\hline Profile 3 & 0.5284 & Profile 2 & 0.5516 & Profile 2 & 0.4498 & Profile 3 & 0.3688 \\
\hline Profile 5 & 0.4848 & Profile 6 & 0.5209 & Profile 6 & 0.4055 & Profile 1 & 0.3152 \\
\hline Profile 6 & 0.4572 & Profile 5 & 0.4855 & Profile 5 & 0.3932 & Profile 5 & 0.3049 \\
\hline Profile 4 & 0.4450 & Profile 1 & 0.4600 & Profile 1 & 0.3701 & Profile 6 & 0.2989 \\
\hline Profile 1 & 0.2876 & Profile 4 & 0.3952 & Profile 4 & 0.3178 & Profile 4 & 0.2181 \\
\hline \multicolumn{8}{|c|}{ Financial Access } \\
\hline \multicolumn{2}{|c|}{ Credit line } & \multicolumn{2}{|c|}{ Bank loan } & \multicolumn{2}{|c|}{ Trade credit } & \multicolumn{2}{|c|}{ Other finance } \\
\hline Profile 6 & 0.6425 & Profile 6 & 0.6563 & Profile 6 & 0.6284 & Profile 6 & 0.7364 \\
\hline Profile 3 & 0.5975 & Profile 5 & 0.6193 & Profile 5 & 0.5934 & Profile 5 & 0.7095 \\
\hline Profile 5 & 0.5959 & Profile 3 & 0.5998 & Profile 3 & 0.5920 & Profile 3 & 0.7080 \\
\hline Profile 2 & 0.5491 & Profile 2 & 0.5608 & Profile 4 & 0.5822 & Profile 2 & 0.6795 \\
\hline Profile 4 & 0.5292 & Profile 4 & 0.5209 & Profile 2 & 0.5559 & Profile 4 & 0.6131 \\
\hline Profile 1 & 0.3932 & Profile 1 & 0.4604 & Profile 1 & 0.5445 & Profile 1 & 0.5329 \\
\hline
\end{tabular}

\section{Conclusions}

SMEs are the engine of the economy. Their share in gross domestic product and employment creation is highly relevant. The financial structure of this type of firms has been frequently studied in the economic literature. Asymmetric information produces serious problems, which preclude several SMEs from easily accessing external resources. This paper explores not only the variables related to the financial current access, but also the variables that affect the application for financial resources.

We found several interesting results. First, firm size affects both the demand and the effective access to finance. In this sense, the smallest firms have lower probabilities in applying for and accessing all of the financial instruments considered in this work. Second, we observe that innovative firms have higher probabilities in demanding financial instruments but lower probabilities in accessing them. These results indicate that innovative firms present higher needs of external financial support, but their access is more limited. Among the problems cited in the literature that magnify the access to finance in this kind of firms are uncertainty regarding the innovation process, long times to delivering the products, intangibility of the main assets of the firms, and the difficulty of reproducing the processes outside the original firms. This paper detects that the demand for external finance in this kind of firms is greater than non-innovative firms, widening the gap between financial supply and demand.

Since the seminal paper by Schumpeter (1942), economists know that innovation is a key economic development driver. Enhancement in productivity and gross domestic product growth is only the visible part of the whole iceberg known as "innovation". In fact, innovation produces a deep spillover effect on society, improving employment quality, and diversity and quality in products and services.

Consequently, economic policies should be oriented to ease the financial access of SMEs. Even though European countries have been developing joint efforts towards it, this paper uncovers that such efforts have not been sufficient in improving the intermediation mechanisms between the financial sector and innovative firms. Therefore, a greater effort and a closer involvement of policy makers with SMEs are considered necessary.

Author Contributions: Methodology, M.B.G. and L.B.M.; software, M.B.G.; formal analysis, M.B.G., L.B.M. and A.F.B.; investigation, M.B.G. and L.B.M.; data curation, M.B.G. and L.B.M.; writing review and editing, M.B.G., L.B.M. and A.F.B.

Funding: This research was partially funded by MINCYT Milstein Grant, Ministerio de Ciencia e Innovación Productiva, Argentina (MINCyT 279/16).

Acknowledgments: The authors would like to thank the European Central Bank (ECB) for the generous provision of SAFE microdata. 
Conflicts of Interest: The authors declare no conflict of interest.

\section{References}

Ang, James S. 1992. On the theory of finance for privately held firms. The Journal of Entrepreneurial Finance 1: 185-203.

Armstrong, Angus, E. Phillip Davis, Iiana Liadze, and Cinzia Rienzo. 2013. Evaluating Changes in Bank Lending to UK SMES over 2001-12-Ongoing Tight Credit? NIESR Discussion Paper. London: NIESR.

Balios, Dimitris, Nikolaos Daskalakis, Nikolaos Eriotis, and Dimitrios Vasiliou. 2016. SMEs capital structure determinants during severe economic crisis: The case of Greece. Cogent Economics and Finance 4: 1-11. [CrossRef]

Banga, Charu, and Amitabh Gupta. 2017. Effect of Firm Characteristics on Capital Structure Decisions of Indian SMEs. International Journal of Applied Business and Economic Research 15: 281-301.

Berger, Allen N., and Gregory F. Udell. 1998. The economics of small business finance: The roles of private equity and debt markets in the financial growth cycle. Journal of Banking E Finance 22: 613-73. [CrossRef]

Brealey, Richard A., Franklin Allen, and Stewart C. Myers. 2006. Corporate Finance, 8th ed. Boston: McGraw-Hill Irwin.

Briozzo, Anahí, Hernán Vigier, and Lisana B. Martinez. 2016. Firm-Level Determinants of the Financing Decisions of Small and Medium Enterprises: Evidence from Argentina. Latin American Business Review 17: 245-68. [CrossRef]

Cassia, Lucio, and Tommaso Minola. 2012. Hyper-growth of smes: Toward a reconciliation of entrepreneurial orientation and strategic resources. International Journal of Entrepreneurial Behavior and Research 18: 179-97. [CrossRef]

Coad, Alex, and Rekha Rao. 2008. Innovation and firm growth in high-tech sectors: A quantile regression approach. Research Policy 37: 633-48. [CrossRef]

Cowling, Marc, Weixi Liu, and Andrew Ledger. 2012. Small business financing in the UK before and during the current financial crisis. International Small Business Journal 30: 778-800. [CrossRef]

Drehmann, Mathias, and Kleopatra Nikolaou. 2013. Funding liquidity risk: Definition and measurement. Journal of Banking and Finance 37: 2173-82. [CrossRef]

European Central Bank. 2017. Survey on the Access to Finance of Enterprises. Methodological Information on the Survey and User Guide for the Anonymised Micro Dataset. Technical Report. Frankfurt: European Central Bank. [CrossRef]

Ferrando, Annalisa, and Klaas Mulier. 2015. Firms' financing constraints: Do perceptions match the actual situation? Economic and Social Review 46: 87-117.

Ferrando, Annalisa, Alexander Popov, and Gregory F. Udell. 2017. Sovereign stress and SMEs' access to finance: Evidence from the ECB's SAFE survey. Journal of Banking and Finance 81: 65-80. [CrossRef]

Forte, Denis, Lucas Ayres Barros, and Wilson Toshiro Nakamura. 2013. Determinants of the capital structure of small and medium sized brazilian enterprises. BAR Brazilian Administration Review 10: 347-69. [CrossRef]

Giudici, Giancarlo, and Stefano Paleari. 2000. The provision of finance to innovation: A survey conducted among italian technology-based small firms. Small Business Economics 14: 37-53. [CrossRef]

Guercio, M. Belén, Lisana B. Martinez, and Hernán Vigier. 2017. Las limitaciones al financiamiento bancario de las Pymes de alta tecnología. Estudios Gerenciales 33: 3-12. [CrossRef]

Guercio, M. Belén, Hernán P. Vigier, Anahí E. Briozzo, and Lisana B. Martínez. 2016. El financiamiento de las pymes del sector de software y servicios informáticos en argentina. Cuadernos de Economía 35: 615-35. [CrossRef]

Hogan, Teresa, and Elaine Hutson. 2005. Capital structure in new technology-based firms: Evidence from the irish software sector. Global Finance Journal 15: 369-87. [CrossRef]

Hogan, Teresa, Elaine Hutson, and Paul Drnevich. 2017. Drivers of external equity funding in small high-tech ventures. Journal of Small Business Management 55: 236-53. [CrossRef]

Iyer, Rajkamal, José-Luis Peydró, Samuel Da-Rocha-Lopes, and Antoinette Schoar. 2014. Interbank Liquidity Crunch and the Firm Credit Crunch: Evidence from the 2007-2009 Crisis. The Review of Financial Studies 27: 347-72. [CrossRef] 
Jimbo Santana, Patricia, Laura Lanzarini, and Aurelio F. Bariviera. 2018. Extraction of Knowledge with Population-Based Metaheuristics Fuzzy Rules Applied to Credit Risk. In Advances in Swarm Intelligence. Edited by Ying Tan, Yuhui Shi and Qirong Tang. Cham: Springer International Publishing, pp. 153-63. [CrossRef]

Jimbo Santana, Patricia, Augusto Villa Monte, Enzo Rucci, Laura Lanzarini, and Aurelio F. Bariviera. 2017. Analysis of Methods for Generating Classification Rules Applicable to Credit Risk. Journal of Computer Science and Technology (JCSET) 17: 20-28.

Kaya, Orcun. 2014. SME Financing in the Euro Area. Deutsche Bank Research. Frankfurt: Deutsche Bank.

Lanzarini, Laura, Augusto Villa Monte, Aurelio F. Bariviera, and Patricia Jimbo Santana. 2015. Obtaining Classification Rules Using LVQ + PSO: An Application to Credit Risk. In Scientific Methods for the Treatment of Uncertainty in Social Sciences. Cham: Springer International Publishing, vol. 377, pp. 383-91. [CrossRef]

Lanzarini, Laura Cristina, Augusto Villa Monte, Aurelio F. Bariviera, and Patricia Jimbo Santana. 2017. Simplifying credit scoring rules using LVQ + PSO. Kybernetes 46: 8-16. [CrossRef]

Lawless, Martina, Brian O'Connell, and Conor O'Toole. 2015. Financial structure and diversification of European firms. Applied Economics 47: 2379-98. [CrossRef]

Lee, Neil, Hiba Sameen, and Marc Cowling. 2015. Access to finance for innovative SMEs since the financial crisis. Research Policy 44: 370-80. [CrossRef]

Martinez, Lisana B., María Belén Guercio, Lilia J. Corzo, and Hernán Vigier. 2017. Determinantes del financiamiento externo de las PyMEs del MERCOSUR. Revista Venezolana de Gerencia 22: 672-92.

Mc Namara, Andrea, Pierluigi Murro, and Sheila O'Donohoe. 2017. Countries lending infrastructure and capital structure determination: The case of European SMEs. Journal of Corporate Finance 43: 122-38. [CrossRef]

Mina, Andrea, Henry Lahr, and Alan Hughes. 2013. The demand and supply of external finance for innovative firms. Industrial and Corporate Change 22: 869-901. [CrossRef]

Minola, Tommaso, Lucio Cassia, and Giuseppe Criaco. 2013. Financing patterns in new technology-based firms: An extension of the pecking order theory. International Journal of Entrepreneurship and Small Business 19: 212-33. [CrossRef]

Modigliani, Franco, and Merton H. Miller. 1958. he cost of capital, corporation finance and the theory of investment. The American Economic Review 48: 261-97.

Modigliani, Franco and Merton H Miller. 1963. Corporate income taxes and the cost of capital: A correction. The American Economic Review 53: 433-443.

Moritz, Alexandra, Joern H. Block, and Andreas Heinz. 2016. Financing patterns of European SMEs-An empirical taxonomy. Venture Capital 18: 115-48. [CrossRef]

Myers, Stewart C. 1984. The Capital Structure Puzzle. The Journal of Finance 39: 574-92. [CrossRef]

Myers, Stewart C., and Nicholas S. Majluf. 1984. Corporate financing and investment decisions when firms have information that investors do not have. Journal of Financial Economics 13: 187-221. [CrossRef]

Öztürk, Bahar, and Mrkaic Mico. 2014. SMEs' Access to Finance in the Euro Area: What Helps or Hampers? IMF Working Paper WP/14/78. Washington, DC, USA: IMF, pp. 1-30.

Pierrakis, Yannis, and George Saridakis. 2019. The role of venture capitalist in the regional innovation ecosystem: A comparison of networking patterns between private and publicly backed venture capital funds. The Journal of Technology Transfer 44: 850-73. [CrossRef]

Rossi, Matteo, Rosa Lombardi, Fabio Nappo, and Raffaele Trequattrini. 2015. The capital structure choices of agro-food firms: evidence from italian smes. International Journal of Management Practice 8: 172. [CrossRef]

Schumpeter, Joseph A. 1942. Capitalism, Socialism and Democracy. New York: Harper \& Brothers.

Serrasqueiro, Zélia, and Ana Caetano. 2015. Trade-Off Theory versus Pecking Order Theory: Capital structure decisions in a peripheral region of Portugal. Journal of Business Economics and Management 16: 445-66. [CrossRef]

Serrasqueiro, Zélia, and Paulo Maçãs Nunes. 2012. Is Age a Determinant of SMEs' Financing Decisions? Empirical Evidence Using Panel Data Models. Entrepreneurship Theory and Practice 36: 627-54. [CrossRef]

Sullivan, Mary O. 2014. Finance and Innovation. In Oxford Handbooks Online. Edited by Jan Fagerberg and David C. Mowery. Oxford: Oxford University Press, pp. 1-19. [CrossRef]

Takalo, Tuomas, and Tanja Tanayama. 2010. Adverse selection and financing of innovation: Is there a need for r\&d subsidies? The Journal of Technology Transfer 35: 16-41. 
Ullah, Farid, and Peter J. Taylor. 2007 Are UK technology-based small firms still finance constrained? The International Entrepreneurship and Management Journal 3: 189-203. [CrossRef]

Wehinger, Gert. 2014. SMEs and the credit crunch: Current financing difficulties, policy measures and a review of literature. OECD Journal: Financial Market Trends 13: 1-34. [CrossRef]

Yazdanfar, Darush, and Peter Öhman. 2015. Debt financing and firm performance: An empirical study based on Swedish data. The Journal of Risk Finance 16: 102-18. [CrossRef]

(C) 2019 by the authors. Licensee MDPI, Basel, Switzerland. This article is an open access article distributed under the terms and conditions of the Creative Commons Attribution (CC BY) license (http:/ / creativecommons.org/licenses/by/4.0/). 